\title{
Emergency reoperation after open heart surgery: ten years of experience
}

\author{
Volkan Yüksel, Serhat Huseyin, Suat Canbaz, Turan Ege, Hasan Sunar \\ Department of Cardiovascular Surgery, Trakya University Faculty of Medicine, Edirne, Turkey \\ Kardiochirurgia i Torakochirurgia Polska 2013; 10 (3): 195-198
}

\begin{abstract}
Background: Postoperative bleeding is an important complication after open heart surgery. Resternotomy for bleeding is an important source of mortality and morbidity.

Aim of the study: We aimed to identify the common sites of bleeding after open heart surgery and to present our results.

Material and methods: We performed 2286 open heart operations from January 2003 to January 2013. Reoperation for bleeding was performed in the case of bleeding that exceeded $3 \mathrm{ml} / \mathrm{kg} / \mathrm{h}$ in the first 3 hours, continued bleeding of more than $200 \mathrm{ml} / \mathrm{h}$ that did not cease, and in the event of clinical signs of tamponade. All patients were reoperated in the operating theatre. Patient data and bleeding sites were recorded.

Results: 98 patients (4.3\%) underwent reoperation for bleeding or tamponade. Non-surgical causes of bleeding were found in 44 patients (44.9\%). The major sites of bleeding were the left side branch of the internal thoracic artery (17.4\%) and the side branch of the saphenous vein graft (13.3\%). Mortality occurred in 13 patients (13.3\%).

Conclusions: Emergency reoperation for bleeding or tamponade after open heart surgery is an important problem. A high percentage of reoperated cases were due to technical errors during graft harvesting. We cannot always avoid the hematologic factors causing bleeding, but we can reduce the number of correctable causes that are usually surgeon-related. This should also contribute to reducing mortality and morbidity after open heart surgery.
\end{abstract}

Key words: cardiac surgery, postoperative bleeding, cardiac tamponade.

\section{Streszczenie}

Wstęp: Krwawienie pooperacyjne jest istotnym powikłaniem po operacjach na otwartym sercu. Resternotomia w celu zatrzymania krwawienia jest istotnym źródłem śmiertelności i chorób.

Cel pracy: Celem pracy było zidentyfikowanie częstych miejsc krwawienia po operacjach na otwartym sercu oraz przedstawienie wyników w tym zakresie.

Materiał i metody: Pomiędzy styczniem 2003 r. a styczniem 2013 r. autorzy niniejszej pracy przeprowadzili 2286 operacji na otwartym sercu. Reoperacja w celu zatrzymania krwawienia wykonywana była w wypadku krwawienia przekraczającego $3 \mathrm{ml} / \mathrm{kg}$ m.c./godz. w ciągu pierwszych 3 godzin, nieustającego krwawienia powyżej 200 ml/godz. lub klinicznych objawów tamponady. Wszystkie reoperacje wykonywano w bloku operacyjnym. Dane dotyczące pacjentów oraz miejsc krwawienia zostały zapisane.

Wyniki: Reoperacji ze względu na krwawienie lub tamponadę zostało poddanych 98 pacjentów (4,3\%). Przyczyny krawienia inne niż operacyjne zaobserwowano u 44 pacjentów (44,9\%). Głównymi miejscami krwawienia były: lewa gałąź boczna tętnicy piersiowej wewnętrznej $(17,4 \%)$ oraz gałąź boczna przeszczepu żyły odpiszczelowej (13,3\%). Zmarło 13 pacjentów (13,3\%).

Wnioski: Pilne reoperacje ze względu na krwawienie lub tamponadę po operacjach na otwartym sercu stanowią poważny problem. Wysoki odsetek ponownie operowanych wynikał z błędów technicznych przy pobieraniu materiału do przeszczepów. Czynników hematologicznych powodujących krawienie nie da się wyeliminować, ale można zmniejszyć liczbę poprawialnych przyczyn, które zazwyczaj zależne są od chirurga. Powinno to przyczynić się do zmniejszenia śmiertelności oraz występowania chorób po operacjach na otwartym sercu.

Słowa kluczowe: kardiochirurgia, krwawienie pooperacyjne, tamponada serca. 


\section{Introduction}

Postoperative bleeding is an important complication after open heart surgery. The proportion of patients undergoing open heart surgery who require reoperation for bleeding has been reported to be between $1 \%$ and $6 \%$ [1-5]. Older age, smaller body mass index, longer cardiopulmonary bypass times, greater number of distal anastomoses, the use of the left internal thoracic artery, repeat cardiac surgery, and combined procedures have been associated with greater risk of resternotomy for bleeding [6, 7]. Such cases are usually hemodynamically unstable and are also at risk of hazards associated with the use of blood and blood products.

\section{Aim of the study}

Resternotomy for bleeding is a significant source of mortality and morbidity [1, 3]. In this study, we aimed to identify the common sites of bleeding after open heart surgery and to present the results of our reoperations.

\section{Material and methods}

We organized a retrospective study based on the database of the hospital records. Approval from the Local Ethical Committee was obtained for the study. All the patients included in the study gave their consent to the scientific analysis of their clinical data in anonymous form.

From January 2003 to January 2013, we performed 2286 operations at our clinic, including coronary artery surgery, valve procedures, aortic procedures, and reoperations. Preoperatively, antiplatelet or antithrombotic drug therapy medications were withdrawn at least five days prior to the operation. Patients on warfarin were switched to low molecular weight heparin prior to the operation. Coagulation profiles were obtained for all patients before operations for bleeding. We preferred pedicled left internal

Tab. I. Clinical characteristics of 98 patients reoperated for bleeding or tamponade

\begin{tabular}{lcc} 
Variable & $n$ & $\%$ \\
Age (years) & $\begin{array}{c}64.3 \pm 12.1 \\
(26-83)\end{array}$ & \\
\hline Male/Female & $64 / 34$ & \\
\hline Ejection fraction (\%) & $\begin{array}{c}51.6 \pm 10.7 \\
(25-70)\end{array}$ & 9.2 \\
\hline Atrial fibrillation & 9 & 4.1 \\
\hline Dialysis-dependent chronic renal & 4 & 6.1 \\
\hline failure & 6 & 36.7 \\
\hline Previous cardiac operation & 36 & 21.4 \\
\hline Smoking & 21 & 19.4 \\
\hline Antiplatelet use & 19 & 12.2 \\
\hline Diabetes mellitus & 12 & 42.9 \\
\hline $\begin{array}{l}\text { Chronic obstructive pulmonary } \\
\text { disease }\end{array}$ & 42 & \\
\hline Hypertension & & \\
\hline
\end{tabular}

mammary artery grafts and great saphenous vein grafts in coronary artery bypass cases. 98 patients (4.3\%) underwent reoperation due to excessive bleeding or because of the clinical suspicion of cardiac tamponade. Data were collected on patient age, sex, performed surgical procedures, preoperative risk factors (such as hypertension, diabetes mellitus, and chronic obstructive pulmonary disease), left ventricular ejection fraction, along with all recorded retrospective data from our hospital records.

Reoperation for bleeding was performed in the case of bleeding that exceeded $3 \mathrm{ml} / \mathrm{kg} / \mathrm{h}$ in the first 3 hours, continued bleeding of more than $200 \mathrm{ml} / \mathrm{h}$ that did not cease, excessive bleeding that restarted (indicating a possible surgical cause), or sudden massive bleeding. Reoperation was also performed in the event of clinical signs of tamponade, such as decreased urine output, tachycardia, hypotension, and increased central venous pressure, often associated with a sudden decrease in chest tube drainage. Excessive pericardial effusion on the transthoracic echocardiogram was also a reason for emergency reoperation. All patients were reoperated in the operating theater.

\section{Results}

Postoperatively, 98 patients (4.3\%) were reoperated: $86(87.8 \%)$ for bleeding and 12 (12.2\%) for tamponade. The mean age was 64.3 ; 64 patients were male and 34 female. The mean duration of reoperation in the intensive care unit was 6 hours. The shortest duration before returning to the operating theater was 20 minutes, whereas the longest duration was 51 hours (in a patient operated for cardiac tamponade). The mean amount of drainage prior to reoperation was $950 \pm 450 \mathrm{cc}$. Clinical characteristics of 98 patients reoperated for bleeding or tamponade are summarized in Table I.

Non-surgical causes of bleeding were found in 44 patients (44.9\%). The most common site of bleeding was the internal thoracic artery side branch, as recorded in 17 patients (17.4\%). Causes of bleeding in the 98 patients are presented in Table II.

The great majority of the reoperations took place after coronary artery bypass surgery (73.5\%). Other reoperations followed valve cases, aortic procedures, and congenital cases, in the order of frequency. Procedures performed on the 98 patients reoperated for bleeding and tamponade are presented in Table III.

Mortality occurred in 13 patients (13.3\%). Eight of these deaths were due to low cardiac output syndrome, 3 were due to pneumonia following prolonged ventilation, 1 was due to mediastinitis, and 1 was due to dialysis-dependent renal failure.

\section{Discussion}

Excessive bleeding following cardiac surgery remains a major source of morbidity and results in longer stay at the intensive care unit and higher mortality [8]. It can result from either surgical errors or impaired hemostasis. Patients reoperated for bleeding or tamponade are also at risk 
Tab. II. Causes of bleeding in 98 patients

\begin{tabular}{lcc} 
Cause of bleeding & $n$ & $\%$ \\
Non-surgical bleeding & 44 & 44.9 \\
\hline Internal thoracic artery side branch & 17 & 17.4 \\
\hline Saphenous vein side branch & 13 & 13.3 \\
\hline Left internal thoracic artery bed & 7 & 7.1 \\
\hline Aortotomy & 4 & 4.1 \\
\hline Distal coronary anastomosis & 4 & 4.1 \\
\hline Internal thoracic artery side branch & 3 & 3.1 \\
\hline and saphenous vein side branch & 2 & 2 \\
\hline Right atriotomy & 2 & 2 \\
\hline Proximal coronary anastomosis & 1 & 1 \\
\hline Retrograde cannula & 1 & 1 \\
\hline Pacing wire & &
\end{tabular}

from the hazards associated with blood and blood product transfusion reactions, viral infections, and immune system suppression [4]. In patients with sudden massive or persistent bleeding, reoperation for hemostasis is necessary. The prevalence of reoperation in our study group was $4.3 \%$ and was similar to that of previously reported articles [3, 8-11].

All patients were reoperated in the operating theater. Charalambous et al. reported that reoperation in the intensive care unit is a safe procedure [12]. The possibility of the need for a cardiopulmonary bypass during reoperation made the operating theater our preferred location for reoperation. This may be related to the patient's hemodynamic status and the surgeon's choice.

The decision concerning reoperation for bleeding should be made earlier in the presence of low hemoglobin levels and unstable hemodynamics. Reoperations may be delayed in the presence of an acceptable level of hemoglobin and evidence that the hemodynamic profile is stable. Since reoperation itself increases the mortality rate, employing a conservative strategy avoiding reoperation has a rationale. Choong et al. reported that early reoperation had a lower mortality rate and shorter intensive care unit stay, while late reoperation was associated with a higher infection rate [13]. We recommend early reoperation if surgical mediastinal bleeding is suspected.

Mediastinal bleeding after cardiac surgery is multifactorial. Hemostatic defects may be related to the exposure of blood elements to the cardiopulmonary bypass circuit. A cardiopulmonary bypass causes a reduction in the levels of coagulation factors, stimulates fibrinolysis, and induces thrombocytopenia and platelet dysfunction [8]. The source of bleeding was non-surgical in $44.9 \%$ of cases. Despite improvements in cardiopulmonary bypass techniques, hematologic problems still pose a significant challenge.

Even in view of the negative aspects of reoperations, they may still be therapeutic due to the removal of clots and consequent reduction of fibrinolytic activity in the mediastinum [14]. The evacuation of clots, which constitute
Tab. III. Procedures in 98 patients reoperated for bleeding and tamponade

\begin{tabular}{lcc} 
Procedure & $n$ & $\%$ \\
Coronary artery bypass & 72 & 73.5 \\
on-pump & 64 & 65.3 \\
off-pump & 8 & 8.2 \\
\hline Valve procedures & 11 & 11.2 \\
aortic + mitral valve replacement & 4 & 4.1 \\
mitral valve replacement & 3 & 3.1 \\
aortic valve replacement & 3 & 3.1 \\
mitral valve replacement + tricuspid repair & 1 & 1 \\
\hline Aortic procedures & 9 & 9.2 \\
\hline Congenital cardiac procedures & 4 & 4.1 \\
\hline Coronary artery bypass + mitral valve repair & 2 & 2 \\
\hline
\end{tabular}

rich culture media for the proliferation of bacteria, is known to help reduce infection rates.

Among the surgical causes, the left side branch of the internal thoracic artery and the side branch of the saphenous vein were the most commonly observed sites. We prefer harvesting the pedicled left internal mammary artery in coronary artery bypass operations. We prefer placing clips to the side branches. The control of the side branches of the left internal mammary artery remains the most important factor in controlling bleeding. The artery is prepared as a pedicle, and the distal part is clipped. This distal portion may also be a source of bleeding and must be checked carefully prior to sternal closure. Then the artery is covered with a cloth soaked with papaverine until anastomosis. The saphenous vein is found at the anterosuperior part of the medial malleolus and is usually one of the most commonly preferred conduits for coronary artery bypass grafting procedures. We use the standard open harvesting technique; side branches of the vein graft are tied with 4/0 silk sutures or clipped. The damage to the saphenous vein graft should be repaired carefully by using 7/0 polypropylene sutures without narrowing the lumen. Aortotomy and atriotomy closures should be achieved with two layers of continuous polypropylene sutures.

In our study group, we found an obvious site of bleeding in $55.1 \%$ of the patients. Karthik et al. reported an obvious site of bleeding in $82 \%$ of patients reoperated for bleeding [2]. In turn, Unsworth-White et al. found an obvious cause in $67 \%$ of the patients [7]. The most common sites of bleeding were: internal thoracic artery side branch (17.4\%), saphenous vein side branch (13.3\%), left internal thoracic artery bed (7.1\%), as well as the sites of aortotomy (4.1\%) and coronary distal anastomosis (4.1\%). Karthik et al. reported the most common sites to be the conduit or the anastomosis (57.5\%), followed by the sternum or internal thoracic artery bed (in $31.5 \%$ of patients) [2]. Unsworth-White et al. found the conduit and anastomosis to be the site of bleeding in $26 \%$ of patients, while in $21 \%$ of cases, the bleeding originated from cannulation and cardiotomy sites [7]. We 
postulate that the patients who continue to bleed after returning to the intensive care unit have a higher possibility of having a surgical site of bleeding.

Reoperations for excessive bleeding or tamponade after cardiac surgery may increase hospital mortality $[3,4,10]$. In our study group, we had a hospital mortality of $3.9 \%$ in patients undergoing cardiac surgery. However, this ratio is nearly tripled $(13.3 \%)$ in patients reoperated for bleeding or tamponade.

\section{Conclusions}

Emergency reoperation after open heart surgery remains an important issue; despite improvements in cardiac surgery, a definite site of bleeding cannot be identified in a large proportion of patients. A high percentage of reoperated cases were due to technical errors during graft harvesting. We cannot always avoid the hematologic factors causing bleeding after cardiac surgery, but we can reduce the number of correctable causes that are usually surgeonrelated. This should also contribute to reducing mortality and morbidity after open heart surgery.

The authors declare no conflict of interest.

The authors received no financial support for the research and/or authorship of this article.

\section{References}

1. Hall TS, Brevetti GR, Skoultchi AJ, Sines JC, Gregory P, Spotnitz AJ. Reexploration for hemorrhage following open heart surgery differentiation on the causes of bleeding and the impact on patient outcomes. Ann Thorac Cardiovasc Surg 2001; 7: 352-357.

2. Karthik S, Grayson AD, McCarron EE, Pullan DM, Desmond MJ. Reexploration for bleeding after coronary artery bypass surgery: risk factors,outcomes, and the effect of time delay. Ann Thorac Surg 2004; 78: 527-534.
3. Ranucci M, Bozzetti G, Ditta A, Cotza M, Carboni G, Ballotta A. Surgical reexploration after cardiac operations: why a worse outcome? Ann Thorac Surg 2008; 86: 1557-1562.

4. Unsworth-White MJ, Herriot A, Valencia O, Poloniecki J, Smith EE, Murday AJ, Parker DJ, Treasure T. Resternotomy for bleeding after cardiac operation; a marker for increased morbidity and mortality. Ann Thorac Surg 1995; 59: 664-667.

5. Toker ME, Eren E, Rabuş MB, Anasız H, Çalışkan A, Güler M, Balkanay M, Yakut $C$. The revision due to bleeding in heart operations: results of a centre in ten years period. Turk Gogus Kalp Dama 2006; 14: 189-193.

6. Sellman M, Intonti MAM, Ivert T. Reoperations for bleeding after coronary bypass procedures during 25 years. Eur J Thorac Cardiovasc Surg 1997; 11: 521-527.

7. Dacey LJ, Munoz JJ, Baribeau YR, Johnson ER, Lahey SJ, Leavitt BJ, Quinn RD, Nugent WC, Birkmeyer JD, O'Connor GT. Reexploration for hemorrhage following coronary artery bypass grafting: incidence and risk factors. Northern New England Cardiovascular Disease Study Group. Arch Surg 1998; 133: 442-447.

8. Canádyová J, Zmeko D, Mokrácek A. Re-exploration for bleeding or tamponade after cardiac operation. Interact Cardiovasc Thorac Surg 2012; 14: 704-707.

9. Kristensen KL, Rauer LJ, Mortensen PE, Kjeldsen BJ. Reoperation for bleeding in cardiac surgery. Interact Cardiovasc Thorac Surg 2012; 14: 709-713.

10. Mataracı I, Polat A, Toker ME, Tezcan O, Erkin A, Kırali K. Postoperative revision surgery for bleeding in a tertiary heart center. Asian Cardiovasc Thorac Ann 2010; 18: 266-271.

11. Mehta RH, Sheng S, O'Brien SM, Grover FL, Gammie JS, Ferguson TB, Peterson ED; Society of Thoracic Surgeons National Cardiac Surgery Database Investigators. Reoperation for bleeding in patients undergoing coronary artery bypass surgery: incidence, risk factors, time trends, and outcomes. Circ Cardiovasc Qual Outcomes 2009; 2: 583-590.

12. Charalambous CP, Zipitis CS, Keenan DJ. Chest reexploration in the intensive care unit after cardiac surgery: a safe alternative to returning to the operating theater. Ann Thorac Surg 2006; 81: 191-194.

13. Choong CK, Gerrard C, Goldsmith KA, Dunningham H, Vuylsteke A. Delayed re-exploration for bleeding after coronary artery bypass surgery results in adverse outcomes. Eur J Cardiothorac Surg 2007; 31: 834-838.

14. Pelletier MP, Solymoss S, Lee A, Chiu RC. Negative reexploration for cardiac postoperative bleeding: can it be therapeutic? Ann Thorac Surg 1998; 65: 999-1002. 